\title{
STUDI KEKERABATAN IKAN FAMILIA CYPRINIDAE YANG TERTANGKAP DI SUNGAI SERAYU KABUPATEN BANYUMAS
}

\author{
Dwi Sekar Putri J, Muh. Nadjmi Abulias, Dian Bhagawati
}

Fakultas Biologi, Universitas Jenderal Soedirman, Jalan dr. Suparno 63 Purwokerto 53122

\section{A B S T RACT}

Cyprinidae is a family of freshwater fish that has quite a lot of valuable members and spread almost all over the world. The purpose of this study was to determine the number of fish of the family Cyprinidae in Serayu River and their relationships. This study used survey method with purposive random sampling. Research materials were members of Cyprinidae taken from the River Serayu Banyumas, which was the collection of Mrs. Dian Bhagawati. The sequence of this study included sample collection, sample preservation, sample observation in the laboratory, i.e., identification, determination of morphological characters and species name of fish and their relationships. Observed variables were morphological characters that included body shape, colors, fins specification, the total and standard length of the body, the shape of the lateral line, the shape of the caudal fin, the position of the mouth, body length, the height and width of the caudal peduncle. The data were then computed to get the coefficient of association among species (S), clustered using UPGMA Cluster Analysis as implemented in Numerical Taxonomy System (NTSYS) version 2.02i. The observed data were also descriptively analyzed based on phenogram obtained. The fish diversity recorded were eight species i.e., Puntius orphoides, Barbodes gonionotus, Osteochilus sp., Osteochilus vittatus, Osteochilus hasselti., Labiobarbus leptocheilus, Cyprinus carpio, and Rasbora sp.. The results showed that the closest relationship based on morphological characteristics was between Puntius orphoides and Rasbora sp. which had the greatest association coefficient of 0.8292 . The smallest value of the association was followed by P. orphoides and Osteochilus sp. with the value of 0.3000. This study was expected to provide information of Cyprinid fish in Serayu River and their phenetic relationship.

KEY WORDS: Identification, relationship, Cyprinidae, Serayu River

Corresponding Author: DIAN BHAGAWATI | email: dian_star05@yahoo.co.id

\section{PENDAHULUAN}

Indonesia memiliki kekayaan spesies ikan sungai yang cukup tinggi. Penelitian sebelumnya yang dilakukan di Sungai Serayu bagian hilir di wilayah Kabupaten Banyumas diperoleh 11 familia, diantaranya berasal dari familia Cyprinidae yang menunjukkan spesies terbanyak yaitu sebanyak 4 spesies (Murtiningsih, 2009). Pada Sungai Rangau di Riau ditemukan 21 familia, 44 genera dan 70 spesies. Familia Cyprinidae merupakan familia paling besar yaitu sebanyak 17 spesies (Yustina, 2001). Ikan yang dikoleksi dari Sungai Serayu di wilayah Kabupaten Wonosobo sebanyak 20 spesies dari 10 familia yaitu familia Cyprinidae sebanyak 8 spesies, Anguilidae sebanyak 2 spesies, Cobitidae, Bagridae, Chanidae, Synbrachidae, Clariidae, Poecilidae dan Chichilidae masing-masing terdiri atas 1 spesies (Kurniasih, 2002).

Familia Cyprinidae memiliki anggota yang sangat beragam, tersebar luas, dan umumnya berperan penting dalam menunjang kehidupan manusia. Menurut Karahan (2010), Cyprinidae merupakan familia ikan air tawar yang terbesar, yang terdiri atas 220 genus dan 2.420 spesies. Banyaknya spesies dari familia Cyprinidae menunjukan kemampuan familia ini untuk beradaptasi dan berkembang biak secara cepat (Beamis et al. 2006). Kekayaan spesies yang tinggi dari familia Cyprinidae pada sungai Rangau Riau yaitu sebanyak 17 spesies dikarenakan sungai ini merupakan tempat bermuara sungai kecil dan merupakan anak sungai dari Sungai Rokan yang merupakan salah satu dari empat sungai terbesar di Riau (Yustina, 2001). Familiia Cyprinidae mempunyai ciri-ciri adanya tonjolan tunggal yang terdapat di kepala atau di bawah mata, pinggir rongga mata bebas atau tertutup oleh kulit, mulut agak ke bawah dan memiliki sungut yang jumlahnya tidak lebih dari 4 helai. Terdapat sambungan tulang rahang yang tidak berbonggol. Sirip punggung biasanya berjari-jari keras dan terletak bertepatan dengan sirip perut (Saanin, 1984).

Hubungan kekerabatan ikan perlu dipelajari untuk mengetahui kedekatan antara spesies ikan yang terdapat di suatu perairan, dan juga memberikan informasi ilmiah dalam bidang taksonomi. Mengenal ciri-ciri morfologi serta jumlah ikan dalam suatu perairan dapat menggambarkan perubahan yang terjadi pada suatu spesies ikan yang kemungkinan disebabkan oleh faktor-faktor lingkungan perairan mengalami proses perubahan (Tjitrosoepomo, 1993). Berdasarkan latar belakang di atas, maka tujuan penelitian ini adalah: mengetahui jumlah spesies ikan familia Cyprinidae yang tertangkap di Sungai Serayu Kabupaten Banyumas, dan mengetahui hubungan kekerabatan ikan dari familia Cyprinidae yang tertangkap di Sungai Serayu Kabupaten Banyumas.

Hasil penelitian ini diharapkan dapat memberikan informasi yang lebih terperinci tentang spesies ikan dari familia Cyprinidae yang tertangkap di Sungai Serayu Kabupaten Banyumas dan kekerabatan fenetiknya. Di samping itu, diharapkan juga dapat digunakan sebagai landasan penelitian selanjutnya serta dapat mendukung upaya konservasi dan budidaya.

\section{E T O D A}

Obyek yang diteliti adalah spesies ikan familia Cyprinidae hasil koleksi Bhagawati et al. (2012) yang tertangkap di Sungai Serayu Kabupaten Banyumas. Bahan yang digunakan dalam penelitian ini adalah ikan familia Cyprinidae yang 
tertangkap di Sungai Serayu Kabupaten Banyumas, aquades, dan alkohol 70\%.

Alat-alat yang digunakan dalam penelitian ini adalah jangka sorong dengan ketelitian $0,01 \mathrm{~cm}$, jarum preparat, penggaris, strereofom, milimeter blok, alat tulis, pinset, baki, kertas label, botol spesimen, kamera digital dan loup. Penelitian ini dilaksanakan di Laboratorium Taksonomi Hewan Fakultas Biologi Universitas Jenderal Soedirman dari Juli sampai September 2012.

Penelitian menggunakan metode survei dengan teknik pengambilan sampel secara Purposive Random Sampling. Sampel berupa ikan hasil tangkapan di Sungai Serayu Kabupaten Banyumas dan merupakan koleksi dari Dian Bhagawati, et al. (2012). Variabel yang diamati adalah karakter morfologi yang meliputi bentuk dan warna tubuh, karakter sisik, karakter spesifik sirip tubuh, bentuk garis rusuk, bentuk sirip ekor, letak mulut, panjang tubuh seluruhnya, panjang tubuh baku, tinggi badan dan tinggi batang ekor.

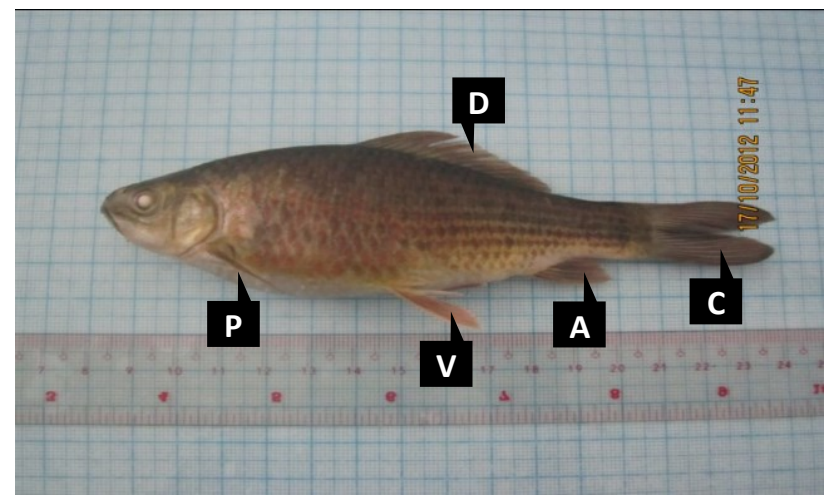

Gambar 1. Morfologi Ikan ( Ket: A = Sirip dubur, C = Sirip ekor, $\mathrm{D}=$ Sirip punggung, $\mathrm{P}=$ Sirip dada, $\mathrm{V}=$ Sirip perut).

Sampel ikan yang diperoleh dikelompokkan berdasarkan kesamaan morfologinya secara makroskopis, kemudian difoto. Ikan dimasukkan ke dalam botol sampel berlabel, kemudian botol diisi larutan alkohol 70\% hingga ikan terendam dan dibiarkan satu malam. Ikan yang telah direndam dicuci dan difiksasi dengan alkohol $70 \%$ dalam botol sampel untuk diidentifikasi.

Karakter morfologi sampel yang tertangkap diidentifikasi dan dideterminasi berdasarkan buku pedoman Taksonomi dan Identifikasi Ikan menurut Saanin (1984) dan Kotellat et al. (1993). Pengamatan dan pengukuran sampel dilakukan terhadap karakter morfologi meliputi: a).Sirip yang terdiri atas sirip punggung, sirip ekor, sirip dada, sirip perut dan sirip dubur. Pengamatan sirip tersebut dilakukan untuk menentukan rumus sirip yang menggambarkan jumlah jari-jari dan bentuk dari sirip; b). Bentuk garis rusuk / linea lateralis, posisi; c). Jumlah sisik, penyusun garis rusuk, jumlah sisik di atas dan di bawah garis rusuk; d).Bentuk sirip ekor ; e). Letak mulut; f). Warna tubuh; g). Panjang tubuh seluruhnya (total length) adalah jarak yang diukur antara moncong paling depan dan ujung sirip ekor paling belakang; h). Panjang tubuh baku (standard length) adalah panjang moncong sampai batang ekor (jarak miring antara ujung dasar sirip dubur dengan pangkal jarijari tengah sirip ekor; i). Tinggi badan adalah jarak terbesar antara garis punggung dan dasar perut; j). Tinggi batang ekor adalah tinggi yang diukur pada batang ekor yang mempunyai tinggi terkecil.

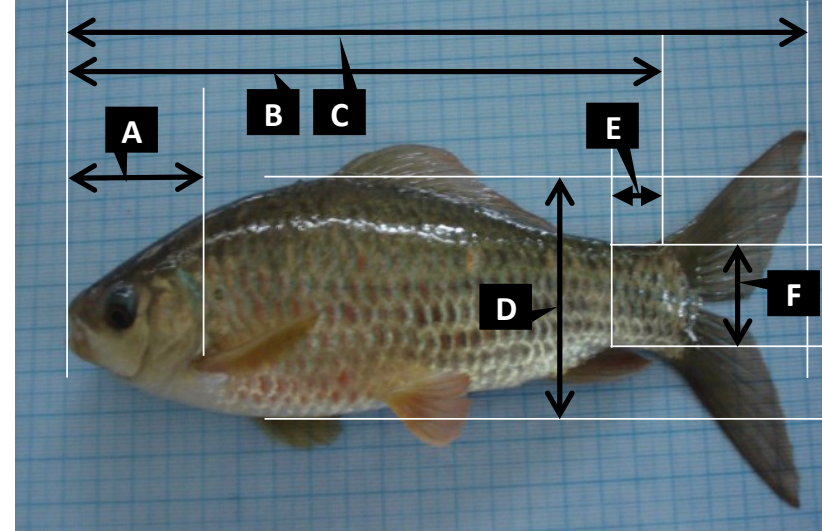

Gambar 2. Bagian-bagian Tubuh yang Diukur (A. Panjang kepala, B. Panjang tubuh baku, C. Panjang tubuh total, D.

Tinggi badan, E. Panjang batang ekor, F. Tinggi ekor).

Hubungan kekerabatan fenetik pada spesies ikan yang didapatkan ditentukan dengan urutan kerja sebagai berikut: a) Menentukan Satuan Taksonomi Operasional, dalam hal ini berupa spesies yang akan dibandingkan; b) Menyeleksi ciri morfologi dari masing-masing sampel yang dapat dibandingkan untuk memberi gambaran secara umum dari ciri satuan taksonomi operasional yang dinyatakan dengan kode biner, artinya yaitu apabila terdapat karakter yang diamati diberi angka 1 dan apabila tidak terdapat karakter yang diamati diberi angka 0 ; c) Menyusun data hasil pengamatan berupa ciri-ciri morfologi ke dalam bentuk tabel atau matrik untuk semua wakil spesies yang merupakan satuan taksonomi; d) Data yang diperoleh dari pengamatan dan pengukuran ditabulasi untuk dianalisis dengan menggunakan NTSYS 2.02i dengan menggunakan koefisien asosiasi (S) untuk mendapatkan data berupa fenogram.

Data yang diperoleh dari hasil identifikasi dan determinasi berdasarkan Kottelat et al. (1993) dihitung analisis hubungan kekerabatannya dengan menggunakan koefisien asosiasi antar spesies (S) dan metode UPGMA Cluster Analysis melalui program Numerical Taxonomy System (NTSYS) versi 2.02i.

\section{HASIL DAN PEMBAHASAN}

Ikan sampel familia Cyprinidae hasil pengambilan dari sungai Serayu Kabupaten Banyumas diidentifikasi menurut Kottelat et al. (1993) diperoleh sebanyak 30 individu dan terdiri atas delapan spesies, yaitu Puntius orphoides terdapat 12 individu, Osteochilus sp. terdapat 4 individu, Labiobarbus leptocheilus terdapat 2 individu, Osteochilus vittatus terdapat 3 individu, Barbodes gonionotus terdapat 2 individu, Cyprinus carpio terdapat 2 individu, Osteochilus hasselti terdapat 2 individu, dan Rasbora sp. terdapat 3 individu. Adapun hasil pengamatan morfologi dari setiap spesies tersebut adalah sebagai berikut.

Puntius orphoides atau lebih dikenal dengan nama Javaen barb mempunyai nama lokal maroca, marococa, wadonon, sisik melik, ampa, dan brek. Bentuk tubuh ikan Brek pipih bilateral dengan panjang kepala 1/5 kali panjang total tubuh. 


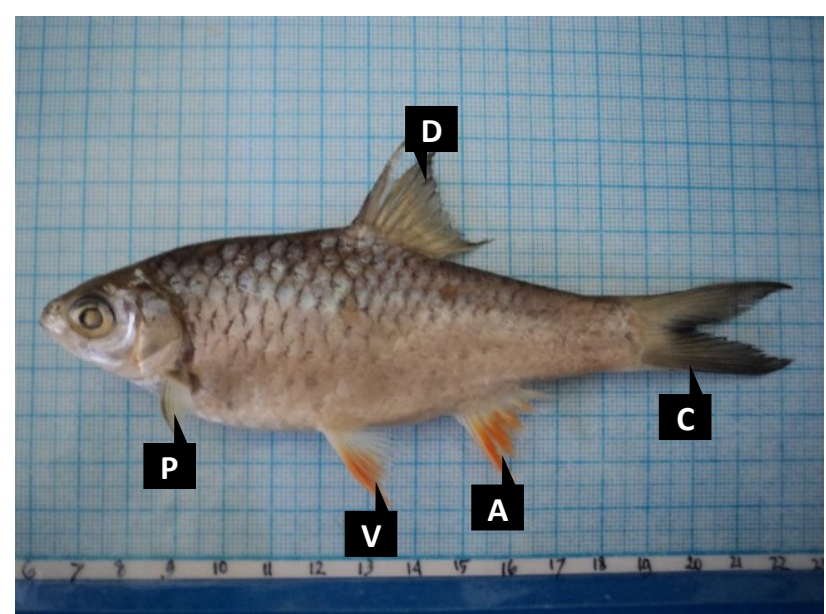

Gambar 3. Puntius orphoides

Panjang tubuh total ikan yang diamati berkisar antara 14-26 cm. Kepala berbentuk pipih dorso lateral dengan posisi mulut terminal, memiliki dua pasang sungut yang terlihat lebih jelas. Tubuh berwarna putih keperakan dan tertutup oleh sisik dengan tipe sikloid. Garis rusuk terletak di atas sirip dada dan memanjang dari belakang tutup insang sampai pertengahan pelipatan ekor dan bagian tengahnya melengkung ke bawah. Garis rusuk tersusun oleh sisik yang berpori dan berjumlah 27-30 keping. Jumlah sisik di atas garis rusuk 7 keping dan di bawah garis rusuk 5 keping. Sirip tersusun oleh jari-jari keras dan lemah dengan rumus sirip: D.I.9; C.19; A.6; V.I.9; P.10. Posisi sirip perut di belakang sirip dada. Jumlah sisik yang mengelilingi batang ekor 16 keping. Selain itu ciri yang sangat jelas dari ikan ini yaitu mempunyai sirip anal dan sirip ventral yang berwarna merah (Gambar 3.).

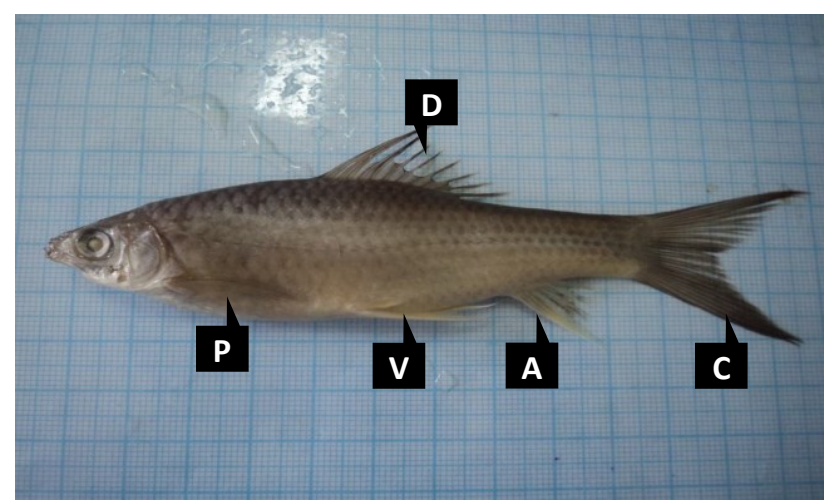

Gambar 4. Osteochilus sp. (Ket: A = Sirip dubur, $\mathrm{C}=$ Sirip ekor, $\mathrm{D}=$ Sirip punggung, $\mathrm{P}=$ Sirip dada, $\mathrm{V}=$ Sirip perut).

Osteochilus sp. memiliki kepala pipih bilateral, warna di atas kepala coklat kehijauan, kepala tidak bersisik, posisi mulut subterminal, tipe mulut dapat disembulkan, mulut relatif sempit, ujung moncong tumpul, rahang atas lebih panjang dari pada rahang bawah, sungut terletak pada sudut mulut, sungut berjumlah dua pasang, bentuk sungut seperti cambuk lubang hidung membuka ke samping, memiliki mata sepasang yang terletak pada kedua sisi kepala.

Badan ikan Osteochilus sp. simetri bilateral, sirip punggung 1 buah, punggung melandai, tidak terdapat bintik kemerahan pada sisik, warna sisik mayoritas putih mengkilap, sisik ventral lebih besar dari pada sisik dorsal, sirip punggung pendek, warna sirip punggung kehitaman. Jumlah sisik pada garis rusuk berjumlah 34-36 keping, sedangkan jumlah sisik di atas dan di bawah garis rusuk masing-masing berjumlah 5-6 dan 4-5 keping. Sirip punggung tanpa duri. Garis rusuk berjumlah 1 dan berbentuk lurus serta tidak memiliki ciri khusus pada tubuh. Sirip punggung memiliki 12-13 jari- jari lemah, sirip dada 11-12 jari-jari lemah, sirip perut 8-9 jari-jari lemah, sirip dubur 5-6 jari-jari lemah dan sirip ekor 16-18 jari-jari lemah. Sirip tersusun oleh jari-jari lemah dengan rumus sebagai berikut D.12-13; C.16-18; A.56; V.8-9; P.11-12. Perbandingan panjang baku dan panjang total tubuh adalah 1:3, panjang kepala $1 / 6$ panjang total tubuh, panjang tubuh total 5 kali tinggi tubuh. Jumlah sisik yang mengelilingi batang ekor 1416 keping, warna sirip ekor kehitaman, tipe sisik sikloid dan sisik batang ekor berwarna kehitaman (Gambar 4).

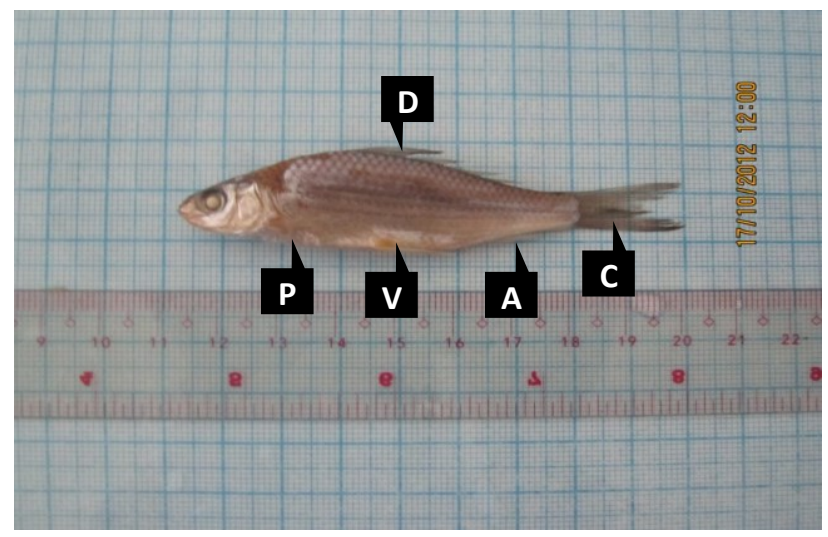

Gambar 5. Osteochilus sp. (Ket: $\mathrm{D}=$ Sirip punggung, $\mathrm{C}=$ Sirip ekor, $\mathrm{P}=$ Sirip dada, $\mathrm{V}=$ Sirip perut, $\mathrm{A}=$ Sirip dubur).

Labiobarbus leptocheilus atau biasa dikenal dengan nama Silver-Shark Barb. Nama lokal Millem, Lokas, Lukas, Umbu-umbu, Siumbut, Wader, Wadon gunung, Wagat (Fishbase, 2011). Ikan siumbut (L. leprocheilus) memiliki 2 pasang sungut pada mulutnya yang digunakan untuk mencari makanan didasar perairan. Bagian sirip dorsal dan kaudal agak kehitam-hitaman, tanpa ditegaskan pola warna yang baik. Pada tubuh dikenali dengan adanya garis rata membujur yang dibentuk dari bintik pada tiap sisik, memiliki ukuran panjang maksimum $30 \mathrm{~cm}$ (Fishbase, 2011). Mempunyai mata tidak berkelopak seperti agar-agar yang lebar dan seperti cincin. Terdapat dua rangkaian pori-pori pada bagian depan moncong hidung. Permulaan sirip dorsal dimuka, di atas atau sedikit dibelakang permulaan sirip ventral (Kottelat, et al., 1993).

Sisik pada garis rusuk berjumlah 36-39 keping, sedangkan jumlah sisik di atas dan di bawah garis rusuk masing-masing berjumlah 8-9 dan 6-7 keping, sirip punggung memiliki 21-28 jari-jari lemah bercabang dan jari-jari tak bercabang yang terakhir dari sirip punggung bertulang. Sirip dada 8-10 jari- 
jari lemah, sirip perut 9 jari-jari lemah, sirip dubur 6 jari-jari lemah dan sirip ekor 18-22 jari-jari lemah. Sirip ekor bercagak tidak bersambungan dengan sirip dubur. Tubuh berbentuk pipih dan putih keperakperakan dengan garis warna gelap pada sirip samarsamar sepanjang deretan sisik. Sirip tersusun oleh jari-jari lemah dengan rumus sirip: D.21-28; C.18-22; A.6; V.9; P.8-10. Jumlah sisik yang mengelilingi batang ekor berjumlah 14 keping (Gambar 5).

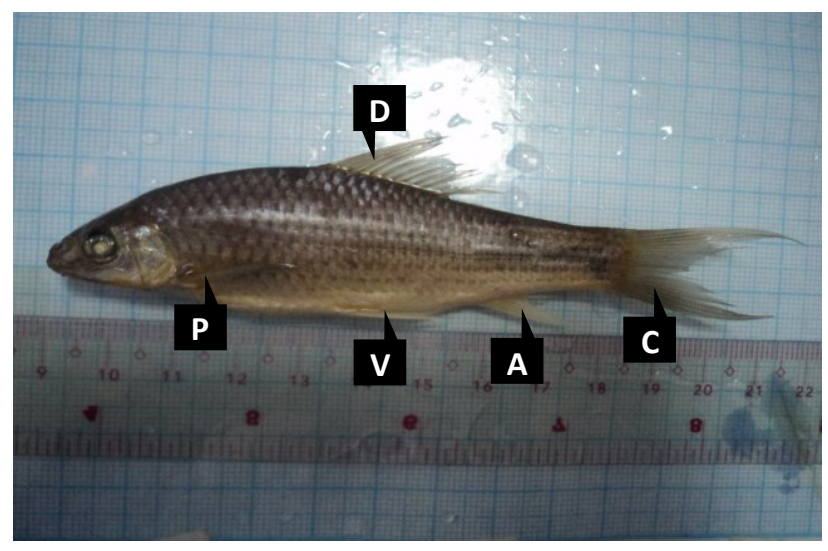

Gambar 6. Osteochilus vittatus (Ket: $\mathrm{D}=$ Sirip punggung, $\mathrm{C}=$ Sirip ekor, $\mathrm{P}=$ Sirip dada, V = Sirip perut, A = Sirip dubur).

Osteochilus vittatus mempunyai bentuk tubuh pipih bilateral dan bentuk kepala pipih dorso lateral, serta panjang kepala 1/6 kali panjang total tubuh. Panjang total tubuh ikan yang diamati berkisar antara 14-15 cm. Tubuh berwarna kuning kehijauan pada bagian dorsal dan berwarna keperakan pada bagian ventral. Posisi mulut subterminal dapat disembulkan, dilengkapi alat tambahan berupa sungut sebanyak dua pasang yang berbentuk seperti rambut dan terletak di sudut mulut. Badan seluruhnya tertutup oleh sisik dengan tipe sikloid. Garis rusuk terletak di atas sirip dada berbentuk lurus ke belakang sampai pertengahan pelipatan ekor. Garis rusuk tersebut tersusun oleh sisik berjumlah 37 keping. Jumlah sisik di atas garis rusuk 6-8 keping dan di bawah garis rusuk 5-7 keping. Sirip tersusun oleh jari-jari lemah dengan rumus sirip: D.13; C.20; A. 6; V.9; P. 12. Posisi sirip perut di belakang sirip dada. Jumlah sisik mengelilingi batang ekor 16 keping. (Gambar 6).

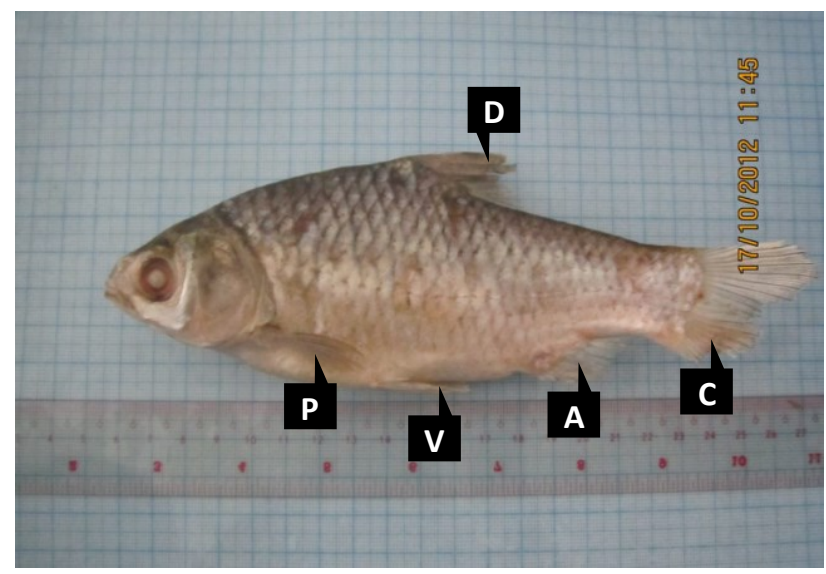

Gambar 7. Barbodes gonionotus (Ket: $\mathrm{D}=$ Sirip punggung, $\mathrm{C}$ $=$ Sirip ekor, $\mathrm{P}=$ Sirip dada, $\mathrm{V}=$ Sirip perut, $\mathrm{A}=$ Sirip dubur).
Barbodes gonionotus atau lebih dikenal dengan nama java carp ini mempunyai nama lokal lawak, lalawak, tarub hawu, bader, putihan, kandia, dan tawes. Bentuk tubuh melebar, pipih bilateral dengan panjang kepala $1 / 5$ kali panjang total tubuh. Selama pengambilan sampel diperoleh sebanyak tujuh ekor yang memiliki panjang total berkisar antara 55-170 mm. Tubuh berwarna putih perak kehitaman yang seluruhnya tertutup oleh sisik dengan tipe sikloid. Bagian lateral tubuh terdapat garis rusuk yang terletak di atas sirip dada dan bentuk bagian tengahnya melengkung ke bawah. Garis rusuk tersusun oleh sisik yang berpori dan berjumlah 29-30 keping. Jumlah sisik di atas garis rusuk 6-8 keping dan jumlah sisik di bawah garis rusuk 3-4 keping. Memiliki sirip yang tersusun oleh jari-jari keras dan lemah dengan rumus sirip: D.II.8; C.20; A.I.8; V.I.8; P.12. Jumlah sisik yang menglilingi batang ekor 15 buah. Kepala berbentuk pipih dorso-lateral dengan posisi mulut terminal dan tidak dapat disembulkan. Memiliki sungut sebanyak dua pasang yang berbentuk seperti rambut dan terletak di sudut mulut (Gambar 7.).

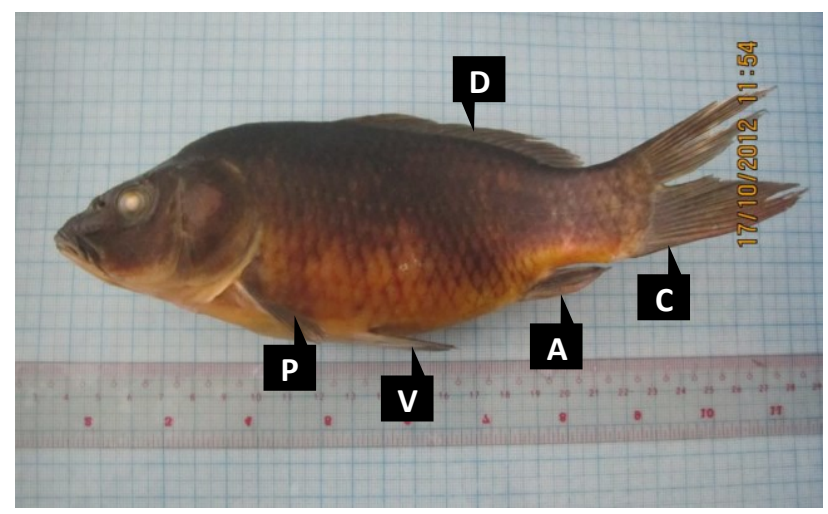

Gambar 8. Cyprinus carpio (Ket: $\mathrm{D}=$ Sirip punggung, $\mathrm{C}=$ Sirip ekor, $\mathrm{P}=$ Sirip dada, $\mathrm{V}=$ Sirip perut, $\mathrm{A}=$ Sirip dubur

Cyprinus carpio memiliki nama lokal yaitu kancra, tikeu, tombro, raja, rayo, dan ameh. Secara morfologi, ikan mas mempunyai bentuk tubuh agak memanjang dan memipih tegak. Mulut terletak di ujung tengah dan dapat disembulkan. Bagian anterior mulut terdapat dua pasang sungut berukuran pendek. Ikan mas memiliki sisik berukuran relatif besar dan digolongkan dalam tipe sisik sikloid.

Ikan Mas mempunyai bentuk tubuh pipih bilateral dan bentuk kepala pipih dorso lateral, serta panjang kepala $1 / 4$ kali panjang total tubuh. Panjang total tubuh ikan yang diamati berkisar antara 20-23 cm. Tubuh berwarna hitam kekuningan pada bagian dorsal dan berwarna kekuningan pada bagian ventral. Posisi mulut terminal dan dapat disembulkan, dilengkapi oleh adanya alat tambahan berupa sungut sebanyak dua pasang yang berbentuk seperti pecut dan terletak di sudut mulut. Garis rusuk terletak di atas sirip dada, berbentuk lurus ke belakang sampai pertengahan pelipatan ekor. Garis rusuk tersebut tersusun oleh sisik yang berjumlah 36-38 keping. Jumlah sisik di atas garis rusuk 8-10 keping dan di bawah garis rusuk 
6-7 keping. Sirip tersusun oleh jari-jari keras dan jarijari lemah dengan rumus sirip D.I.20; C.20; A.I.6; V.10; P.14. Posisi sirip perut terletak dibelakang sirip dada. Jumlah sisik yang mengelilingi batang ekor 16 keping (Gambar 8.).

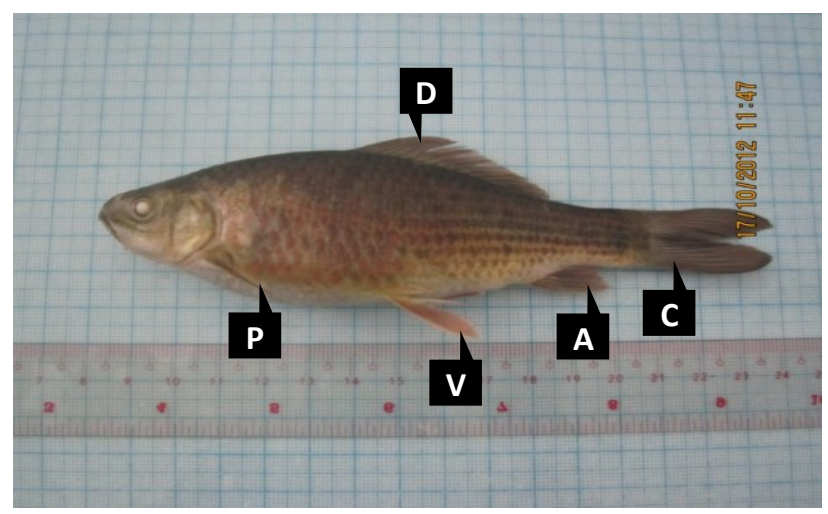

Gambar 9. Osteochilus hasselti (Ket: D = Sirip punggung, $\mathrm{C}=$ Sirip ekor, $\mathrm{P}=$ Sirip dada, $\mathrm{V}=$ Sirip perut, $\mathrm{A}=$ Sirip dubur

Badan ikan nilem mangut simetri bilateral, sirip punggung 1 buah, punggung melandai, terdapat bintik kemerahan yang jelas pada sisik bagian ventral, sisik ventral lebih besar dari pada sisik dorsal, sirip punggung pendek, warna sirip punggung kehitaman, warna sirip perut kemerahan dan warna sirip dubur kehitaman. Jumlah sisik pada garis rusuk 37-38 keping, sedangkan jumlah sisik di atas dan di bawah garis rusuk masing-masing berjumlah 8-9 keping dan7-8 keeping. Sirip punggung tanpa duri. Posisi sirip perut dan sirip dada adalah abdominal, sirip dubur pendek dan garis rusuk berada di atas sirip dada. Garis rusuk berjumlah satu dan berbentuk lurus serta tidak memiliki ciri khusus pada tubuh. Rumus jari-jari sirip pada nilem mangut yaitu sebagai berikut, D.15; C.20; A.6; V.9; P.12. Panjang kepala 1/6 panjang total tubuh, panjang tubuh total 4 kali tinggi tubuh dan perbandingan panjang baku dan panjang total tubuh adalah 1:3 (Gambar 9.).

Bentuk tubuh pipih bilateral dan bentuk kepala pipih dorso lateral. Tubuh kecil ramping dengan panjang berkisar antara 6-8 cm. Tubuh berwarna coklat kekuningan di bagian atas (dorsal) dan putih keperakan di sisi bagian bawah (ventral). Terdapat sebuah garis kehitaman di bagian luar kulit pada masing- masing sisi tubuh mulai dari belakang tutup insang hingga ke batang ekor. Ikan ini mempunyai posisi mulut terminal serta memiliki dua pasang sungut. Badan seluruhnya tertutup oleh sisik dengan tipe sisik sikloid.

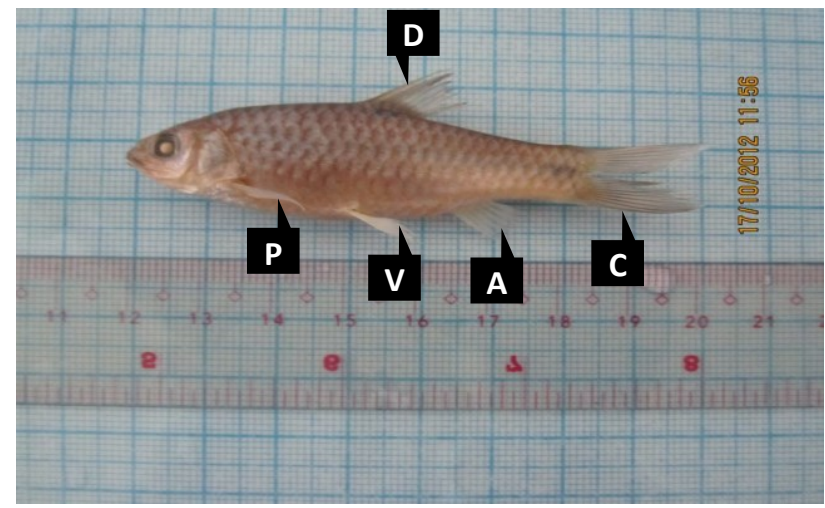

Gambar 10. Rasbora sp (Ket: D = Sirip punggung, C = Sirip ekor, $\mathrm{P}=$ Sirip dada, $\mathrm{V}=$ Sirip perut, $\mathrm{A}=$ Sirip dubur).

Garis rusuk yang terletak di atas sirip dada berbentuk melengkung ke bawah, tersusun oleh sisiksisik yang berjumlah 31 keping. Sementara itu, jumlah sisik di atas garis rusuk 6 keping dan jumlah sisik di bawah garis rusuk 4 keping. Sirip lengkap tersusun oleh jari-jari keras dan lemah dengan rumus sirip: D.I.8; C.20; A.6; V.9; P.10. Posisi sirip perut terletak di belakang sirip dada. Jumlah sisik yang mengelilingi batang ekor 12 keping. (Gambar 10).

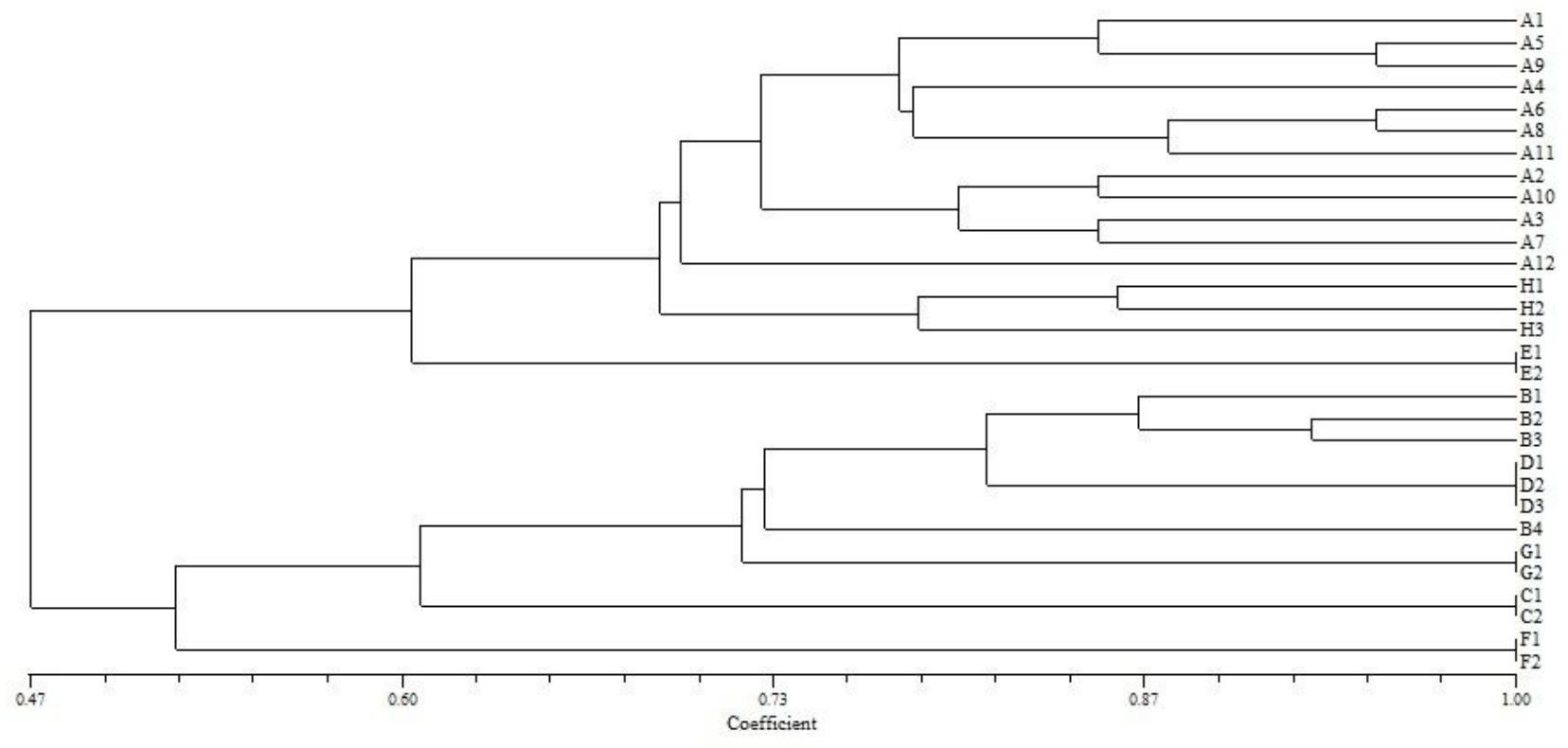

Gambar 11. Fenogram Hubungan Kekerabatan Ikan Familia Cyprinidae yang Tertangkap di Sungai Serayu Kabupaten Banyumas (Ket: A. Puntius orphoides,B. Osteochilus sp., C. Labiobarbus leptocheilus, D. Osteochilus vittatus, E. Barbodes gonionotus, F. Cyprinus carpio, G. Osteochilus hasselti, H. Rasbora sp.). 
Berdasarkan karakter morfologi yang dimiliki oleh masing-masing ikan, kemudian dihitung nilai koefisien asosiasinya. Nilai tersebut dapat ditentukan dengan cara membandingkan karakter morfologi yang terdapat pada semua spesies ikan yang termasuk dalam Operational Taxonomic Unit (satuan taksonomi operasional). Berdasarkan karakter morfologi yang teramati dan dianalisis Cluster, maka diperoleh matriks hubungan kekerabatan antar spesies pada Tabel 1. dan fenogram pada Gambar 11.

Berdasarkan perhitungan koefisien asosiasi dan fenogram kekerabatan (Gambar 11) yang terbentuk, diperoleh bahwa ikan yang tertangkap dapat dibedakan menjadi 3 kelompok, yaitu kelompok I terdiri atas Puntius orphoides, Rasbora sp. dan Barbodes gonionotus. Kelompok II terdiri atas Osteochilus sp., Osteochilus vittatus, Osteochilus hasselti, dan Labiobarbus leptocheilus. Kelompok III terdiri atas Cyprinus carpio.

Kelompok Puntius orphoides dan Rasbora sp. memiliki hubungan kekerabatan yang relatif erat, dengan nilai koefiseien asosiasi (S) yaitu sebesar 0,8292 . Kedua spesies tersebut mempunyai ciri morfologi yang sama antara lain (1) posisi mulut terminal, (2) garis rusuk bagian tengah melengkung ke bawah, (3) mempunyai dua pasang sungut dan sirip ekor bercagak, (4) memiliki ciri khusus pada tubuh yaitu, pada $P$. orphoides bagian sirip dubur dan sirip perut berwarna merah, sedangkan pada Rasbora sp. cirri khusus terdapat pada bagian sirip punggung dan sirip perut berwarna kehitaman serta pada batang ekor terdapat bintik hitam yang jelas. Perbedaan antara kedua spesies tersebut yaitu pada $P$. orphoides memiliki panjang dasar sirip punggung dibandingkan dengan panjang total tubuh 1:11, sedangkan pada Rasbora sp. panjang dasar sirip dubur dibandingkan dengan panjang total tubuh 1:10. Kelompok Puntius orphoides dan Barbodes gonionotus merupakan spesies yang cukup dekat hubungan kekerabatannya. Hal ini dapat diketahui dari nilai koefisien asosiasinya $(S)$ yaitu sebesar 0,7000 . Kedua spesies tersebut mempunyai ciri morfologi yang sama, antara lain (1) posisi mulut terminal dan dapat disembulkan, (2) garis rusuk bagian tengah melengkung ke bawah, (3) mempunyai dua pasang sungut, (4) perbandingan panjang baku dan panjang total tubuh $1: 3$, (5) panjang kepala $1 / 6$ panjang tubuh total, (6) tinggi tubuh $1 / 4$ panjang total tubuh. Perbedaan antara kedua spesies tersebut yaitu perbandingan panjang kepala dengan panjang total tubuh pada Puntius orphoides $1 / 6$, sedangkan pada Barbodes gonionotus perbandingan panjang kepala dengan panjang tubuh total $1 / 4$.

Hubungan kekerabatan terdekat juga dimiliki oleh spesies Osteochilus sp.1 dan Osteochilus vittatus hal ini dapat diketahui dari nilai koefisien asosiasinya (S) 0,8500 . Keduanya mempunyai ciri morfologi antara lain (1) posisi mulut sub terminal dan dapat disembulkan, (2) mempunyai dua pasang sungut berbentuk pecut dan sungut terletak pada sudut mulut, (3) panjang kepala 1/6 panjang tubuh total, (4) perbandingan panjang baku dan panjang total tubuh 1:3, (5) panjang total tubuh 6 kali panjang dasar sirip punggung dan kedua spesies tersebut dalam kategori genus yang sama yaitu Osteochilus. Ciri morfologi yang membedakan kedua spesies ini adalah panjang dasar sirip dubur dibandingkan dengan panjang tubuh total 1:13 pada Osteochilus sp., sedangkan pada Osteochilus vittatus panjang dasar sirip dubur dibandingkan dengan panjang tubuh total yaitu 1:10.

Panjang sirip dada Osteochilus sp.1 jika di bandingkan dengan panjang total tubuh yaitu $1 / 6$, sedangkan pada Osteochilus sp.2 panjang sirip dada jika dibandingkan dengan panjang total tubuh yaitu 1/7. Nilai koefisien asosiasi terkecil yaitu 0,3000 dimiliki oleh Puntius orphoides dan Osteochilus sp. yang mempunyai perbedaan posisi mulut, bentuk garis rusuk, ada tidaknya ciri khusus pada tubuh dan kedua spesies tersebut dalam kategori genus yang berbeda.

Mayr dan Ashlock (1991) berpendapat bahwa umumnya karakter morfologi menggambarkan sebagian besar dari sifat genotip. Karakter morfologi sering digunakan untuk melengkapi dan menambah luas karakter lain, untuk lebih memperjelas sebabsebab perbedaan pada karakter morfologi, maka perlu digunakan karakter taksonomi lain seperti molekuler, kromosom, dan filogeni.

\section{KESIMPULAN DAN SARAN}

Familia Cyprinidae yang tertangkap di Sungai Serayu Kabupaten Banyumas sebanyak 8 spesies yaitu Puntius orphoides, Osteochilus sp., Labiobarbus leptocheilus, 0. vittatus, Barbodes gonionotus, Cyprinus carpio, O. hasselti, dan Rasbora sp. Hubungan kekerabatan terdekat antara Puntius orphoides dan Rasbora sp. dengan nilai koefisien asosiasi (S) 0,8292. sedangkan hubungan kekerabatan terjauh antara $P$. orphoides dengan Osteochilus sp., dengan nilai koefisien asosiasi ( $\mathrm{S}$ ) 0,3000 .

Penelitian ini merupakan informasi mengenai kekerabatan spesies yang termasuk dalam familia Cyprinidae berdasarkan karakter morfologinya yang tertangkap di Sungai Serayu Kabupaten Banyumas, Sehingga untuk mendapatkan data yang lebih akurat perlu dilakukan penelitian lebih lanjut untuk mengetahui hubungan kekerabatan familia Cyprinidae dapat dilihat dari jumlah vertebrae atau dengan karakter molekuler.

\section{DAFT AR REFERENSI}

Beamis FWH, Saadrit P, Tongnunui S. 2006. Habitat characteristics of the Cyprinidae in small rivers in central Thailand. Journal Enviromental Biology of Fishes. 76:2-4.

Bhagawati D. 2012. Karakter Mulut dan Variasi Struktur Gigi pada Familia Bagridae yang Tertangkap di Sungai Serayu Kabupaten Banyumas. Jurnal Depik, 1(3):144-148

Fishbase. 2011 Spesies summary: Karahan A, Ergene S. 2010. Cytogenetic analysis of Garra variabilis (Heckel, 1843) (Pisces, Cyprinidae) from savur stream (Mardin), Turkey. Turkish Journal of Fisheries and Aquatic Sciences.10:483-489. [disitasi 29 September 2012]. Tersedia di http://www.fishbase.org. 
Kottelat M, Whitten AJ, Kartikasari SN, Wirjoatmojo D. 1993. Freshwater fishes of Western Indonesia and Sulawesi (Ikan air tawar indonesia bagian barat dan Sulawesi). Jakarta: Periplus Edition Limited.

Kurniasih E. 2002. Analisis struktur komunitas ikan pada Sungai Serayu di Wilayah Kabu-paten Wonosobo. [Skripsi]. Fakultas Biologi Universitas Jenderal Soedirman, Purwokerto

Mayr E, Ashlock PD. 1991. Principles of systemic zoology. Singapore: McGraw-Hill Book Co.
Murtiningsih D. 2009. Struktur komunitas dan distribusi ikan dibagian hilir sungai serayu [Skripsi]. Fakultas Biologi Universitas Jenderal Soedirman-Purwokerto.

Saanin H. 1984. Taksonomi dan kunci identifikasi ikan jilid I dan II. Bandung: Bina Cipta.

Tjitrosoepomo G. 1993. Taksonomi umum. Yogyakarta: Gadjah Mada University Press.

Yustina. 2001. Keanekaragaman spesies ikan di sepanjang perairan sungai rangau, Riau Sumatera. Jurnal Nature Indonesia. 4:1-14. 